\title{
Government Efficiency and the Market Metaphor
}

The Myth of Democratic Failure. By Donald Wittman." Chicago and London: University of Chicago Press, 1995. Pp. ix, 229. \$29.95.

During the past fifteen years, a growing cadre of social scientists has used the tools of economic analysis to argue that when governments act, they do so inefficiently. ${ }^{1}$ In The Myth of Democratic Failure, Donald Wittman suggests that these social scientists have it all wrong. He sets out to prove that government institutions, like traditional economic markets, are "organized to promote wealth maximizing outcomes." If accepted, Wittman's thesis promises to reorient the efforts of economists, lawyers, and political scientists who currently approach political institutions with a presumption of inefficiency (p. 192). In the process, Wittman seeks to provide a new "research agenda" to guide future efforts at explaining democratic behavior (p. 3). Although Wittman produces an exceptionally clear and engaging new look at a contentious field, his ambitious broader goal-to "develop a consistent theoretical approach" to political markets (p. 2)-remains ultimately unfulfilled.

Wittman's work is less an affirmative account of governmental efficiency than a sweeping attack on the conventional view that political markets fail. Wittman seeks to debunk the "pessimistic views of democracy" that assume

* Professor of Economics, University of California, Santa Cruz.

1. This view may best be summed up by (noneconomist) P.J. O'Rourke's quip that "giving money and power to government is like giving whiskey and car keys to teenage boys." P.J. O'ROURKE, PARLIAMENT OF WHORES at xviii (1991). This view (though in more reserved terms) pervades the social science literature examining political institutions from an economic perspective. See, e.g., RANDALL G. HOLCOMBE, AN ECONOMIC ANALYSIS OF DEMOCRACY (1985); Barty R. Weingast et al., The Political Economy of Benefits and Costs: A Neoclassical Approach to Distributive Politics, 89 J. POL. ECON. 642 (1981); see also DONALD P. GREEN \& IAN SHAPIRO, PATHOLOGIES OF RATIONAL CHOICE THEORY 3-4 (1994) (arguing that economic models have "raised the possibility that democratic institutions might be profoundly dysfunctional"). Wittman notes that even when "economists have made positive remarks about the efficacy of political markets ... such remarks are hidden in books and articles that are overwhelmingly critical" (p. 1 n.1).

2. Indeed, Wittman uses the term "democratic market" to capture the efficiency analogy he draws between the economic and political spheres (p. 3). 
that "irrationality of voters, shirking by politicians, or rent seeking by special interests" condemns governments to produce inefficient results (p. 152).

In the first part of his analysis, Wittman challenges what he claims is at the core of the standard argument for democratic-market failure: The assumption that voters are ignorant. Under this assumption, voters are uninformed because the cost of obtaining enough information to cast a ballot is higher than the power of any one vote (p. 9). ${ }^{3}$ Voters are also barraged with inaccurate and self-serving campaign material, creating "mistaken and biased judgments" (p. 38). Wittman counters this view by showing that it ignores voters' use of information-gathering shortcuts to choose the right candidate (pp. 12-15). He argues that political parties provide a "brand name" and reputation by which voters can assess the political positions of candidates (p. 21). Similarly, interest groups and the mass media provide access to "free" political data. Wittman also argues that voters are rarely influenced by biased or misleading information. Competition among candidates and the public's ability to discount the credibility of biased sources minimize the effect of such information on electoral outcomes (pp. 16, 22).

The conventional view of electoral politics also assumes a weak relation between the preferences of voters and the behavior of their elected officials. Self-serving legislators and influential interest groups prevent majority preferences from being identified and met (pp. 27-30). Wittman takes this view to task by arguing that competition within political markets forces politicians to maintain fidelity to voter preferences once elected. Challengers gain by publicizing evidence of an incumbent's shirking her public duty while in office (p. 22). Political parties, to maintain their value as "brand names," monitor their elected members to prevent a deterioration of the parties' reputations (p. 21). Wittman also uses competition to explain away the perception that pressure groups exert influence over electoral results, highlighting evidence that majority preferences generally trump interest group views (pp. 79, 84-85).

The second part of Wittman's argument challenges conventional accounts of democratic-market failure, which, according to Wittman, posit that government institutions, marked by high transaction costs and rampant rent seeking, inefficiently allocate political wealth. ${ }^{4}$ In contesting this view, Wittman argues that government institutions are overwhelmingly designed to lower the costs of transactions between political actors and to allocate rents efficiently. Congress, for example, facilitates exchange through representation, which lowers the number of parties that must negotiate to make collective

3. This view of "rational abstention" was first developed in ANTHONY DOWNS, AN ECONOMIC THEORY OF DEMOCRACY 260-74 (1957).

4. Wittman states that "[p]olitical markets are inefficient when one group of actors does not account for the costs or benefits to another group of actors" (p. 31). The distribution of political wealth is not as important for efficiency as the notion that it is allocated at the least cost to society (p. 37). 
national decisions (p. 66). ${ }^{5} \mathrm{He}$ further contends that political parties efficiently produce legislation by steering it through the specialized committee system (pp. 69-75). Pressure groups, for their part, improve efficiency by providing low-cost information to constituents and elected officials (p. 81). Wittman argues that even bureaucratic institutions, long the paradigm of inefficiency, actually perform regulatory tasks optimally (pp. 109-11). ${ }^{6}$

Wittman also attacks the conventional view that rent seeking in government is prevalent, citing empirical data suggesting that such activity is minimal (p. 36). Combining this argument with evidence that interest groups have less influence than commonly thought, Wittman suggests that government institutions are not manipulated at the voters' expense (pp. 84-85). ${ }^{7}$

Finally, Wittman concludes by examining how the political and institutional elements of democratic markets affect the distribution of political and economic wealth-ground rarely covered by economists. Throughout the book, Wittman echoes most economists by contending that, regardless of one's view of the distributive ends of government, an efficient means of reaching those ends will always be preferable (p. 162). Wittman also argues, however, that government policy has little ability to affect the distribution of wealth, as exchanges are made in the marketplace to offset government action. ${ }^{8}$ Further, Wittman contends that competition between groups seeking government resources prevents powerful elites from shifting wealth to themselves (pp. 174-76, 192). Wittman closes his book by suggesting that future research start with the presumption that political markets are efficient rather than the standard, opposite expectation, and begin to focus on what activities may best take advantage of the efficiency of government institutions (pp. 188-91).

5. Other phenomena, such as "logrolling," where representatives trade votes on various issues, facilitate socially beneficial legislation. Though usually thought to be inefficient, Wittman contends that logrolling produces beneficial bargains between majority-minority coalitions in order to enact legislation (pp. 32-33).

6. To the extent that any inefficiency is found in government institutions, Wittman argues that the nature of the activity itself might be unsuitable for the market, and for that reason delegated to government control (p. 187).

Wittman extends his discussion of efficiency and transaction costs even to the level of constitutional structure, arguing that the allocation of legislative and enforcement duties between Congress and the President may "best exploit the benefits from the division of labor" between the branches (p. 127). Wittman contends that federalism is similarly efficiency-enhancing (pp. 130-34). Cf. Richard A. Posner, The Constitution as an Economic Document, 56 GEO. WASH. L. REV. 4, 10-16 (1987) (examining economic benefits of federalism and separation of powers). Wittman also provides efficiency explanations for the Takings Clause (pp. 137-48), judicial interpretation (pp. 128-30), and zoning (pp. 116-21).

7. To the extent that rent seeking does exist, Wittman contends that political actors will maximize efficiency anyway, in order to maximize "the gain that rent seekers can extract" (p. 34). For example, under this theory, the defense industry would not lobby for more weaponry than needed, but would rather press for higher profit margins (p. 35).

8. For example, legislation placing the risk of liability on a manufacturer for defective products merely forces the manufacturer to provide insurance for consumers and charge more for the product. Any redistributive goal is preempted by the market (pp. 166-73). This concept was first systematically explored, of course, in R.H. Coase, The Problem of Social Cost, 3 J. LAw ECON. 1 (1960). 
Wittman's book offers a broad, critical survey of the existing empirical work on, and a unified theory of, democratic-market efficiency. His comprehensive critique of the efficiency literature approaches the "cure" he seeks for the "schizophrenia facing most economists, who believe that economic markets work well, but political markets work poorly" (p. 2). ${ }^{9}$ Wittman, however, endeavors to extend the implication of his arguments to "overcome the blindness of many sociologists" to models of "rational behavior and competition" and to "help political science... develop a consistent theoretical approach" (p. 2). It is in these broader aspirations that Wittman's work may disappoint, as his treatment of these interdisciplinary issues is less persuasive than his economic analysis.

Wittman suggests that, just as self-interested behavior in economic markets is collectively beneficial, so too selfish political behavior can maximize the public good. ${ }^{10}$ Yet other behavioral factors remain unexplored because Wittman is wedded to the wealth maximization metaphor. In describing the electoral market, for example, he ignores arguments that "symbolic politics,"11 emotional content, and even "entertainment" may subvert rationality in the voting calculus. ${ }^{12}$ If motivation is actually a more complicated formula, efficiency concerns may not sufficiently dictate the actions of many officeholders. ${ }^{13}$ Broader assumptions than mere wealth maximization may explain institutional design and function more completely. ${ }^{14}$ Though Wittman

9. See, e.g., Herbert Hovenkamp, Rationality in Law \& Economics, 60 GEO. WASH. L. REV. 293, 338 (1992) (noting that "if we begin with the premise that [legislative] markets are imperfect and anticompetitive, we will likely find plenty of evidence").

10. Downs had doubts about making this generalization. See DowNS, supra note 3, at 280-93.

11. See, e.g., MuRRay Edelman, The Symbolic USES of Politics 5 (1964) (arguing that "[p]olitics is for most of us a passing parade of abstract symbols"); SAMUEL L. POPKIN, THE REASONING VOTER 102-07 (2d ed. 1994) (discussing prevalence and influence of political symbols).

12. Daniel Shaviro, Beyond Public Choice and Public Interest: A Study of the Legislative Process as Illustrated by Tax Legislation in the 1980s, 139 U. PA. L. REV. 1, 78-80 (1990). But see Gary S. Becker, Nobel Lecture: The Economic Way of Looking at Behavior, 101 J. PoL. ECON. 385, 403 (1993) ("The rational choice model provides the most promising basis presently available for a unified approach to the analysis of the social world by scholars from different social sciences.").

13. See Shaviro, supra note 12, at 80-87 (positing that elements of "prestige" or "power" may influence legislative decisionmaking). Nothing rules out altruistic reasons for service as well. Wittman makes the argument that politicians remain in office to retain "above-market salaries" (p. 27); an expansive view suggests that this need not be the case. See Downs, supra note 3, at 292 ("Thus self-interest may be a far cry from a simple desire for high income or sweeping power; its forms may even be highly beneficial to society."); Shaviro, supra note 12, at 80 (suggesting that "[e]lected positions often pay less than the available private sector alternatives").

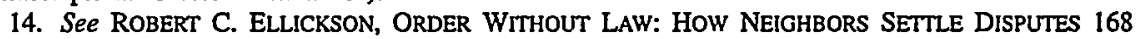
(1991) (discussing superiority of more inclusive measure of "welfare maximization" over traditional "wealth maximization"); Bernard Grofman, Public Choice, Civil Republicanism, and American Politics: Perspectives of a "Reasonable Choice" Modeler, 71 TEX. L. REV. 1541, 1581-83 (1993) (contending that economic views of democracy, alone, may ignore "republican" traditions); Herbert Hovenkamp, Legislation, WellBeing, and Public Choice, 57 U. CHI. L. REV. 63, 110-14 (1990) [hereinafter Hovenkamp, Well-Being] (arguing that strict wealth maximization may ignore hidden elements of "social utility"). Even Downs 
does not claim to "explain all of democratic politics" (p. 192), by ignoring this larger scholarly debate he leaves himself open to the charge that his account has little explanatory force.

But how well does Wittman perform on his home turf, taking for granted the usual economic assumptions? He does skillfully expose false assumptions in the social scientific literature. For example, Wittman dismisses studies that question the correlation between voter preferences and legislative behavior by attacking econometricians' flawed use of "proxies" in their models (p. 28). To reject conventional views of majority-vote preference aggregation, Wittman constructs an elaborate model to prove that legislative policy is wealth maximizing (pp. 154-58).

At other times, though, Wittman's logic is less than compelling, especially when he approaches the limits of his expertise. Wittman argues that, appearances aside, it is "silly to blame Congress" for the effects of interest groups when voters support similar positions in ballot initiatives (pp. 83-84). This argument, though, doesn't deal squarely with the extensive literature showing at least some pressure group influence on legislative outcomes, especially in referenda. ${ }^{15}$ Similarly, Wittman instinctively falls back on "competition" to explain adverse empirical results in areas such as zoning (p. 117), bureaucratic markets (p. 95), and elections (p. 23), even when doing so ignores these studies' underlying rationales. ${ }^{16}$

Taken together, these criticisms may leave a reader unsatisfied with Wittman's analysis from either a purely economic or a broader perspective. His treatment of distributional issues is illustrative. Wittman maintains, with most economists, that the distribution of political and economic wealth is irrelevant to determining the efficiency of government behavior, and that, at any rate, the ability of governments to redistribute is exaggerated. However, he also attacks the argument that "politically powerful elites" manipulate the distribution of wealth, arguing that competition between elites and among officeholders undermines any potential shift in wealth (pp. 174-76). Wittman concludes with a deceptively simple syllogism:

Democracies provide equal votes, but if the voters are poorly informed or there is little competition, then some actors may be extremely powerful. But here I have argued that voters make informed judgments and that democratic markets are competitive. I have thereby undermined the intellectual foundations of theories that claim political

seemed to recognize that "social welfare" may involve more than pure economic utility. See DownS, supra note 3 , at 286.

15. See, e.g., BETTY H. ZISK, MONEY, MEDIA, AND THE GRASS ROOTS: STATE BALlor ISSUES AND THE ELECTORAL PROCESS (1987).

16. Wittman at times even ascribes political motivations to writers who disagree with him, explaining away some observed rent seeking as being "in the eye of the beholder" and suggesting that examples of political-market failure merely reflect "dissatisfaction]" with the chosen policy (pp. 36, 182). 
power is concentrated in the hands of corporations or a small class of individuals (p. 192).

Even assuming that both of Wittman's premises are correct, it seems unbelievable to suggest that our system is thereby free from inequality. Such simplicity, at the very least, trivializes the complexity of both voter behavior and government functions. ${ }^{17}$ Transfers of wealth seem to be at the very core of much of what government does. ${ }^{18}$ Indeed, the larger debate about the goal of efficiency itself sees distributional issues as part of voters' and politicians' broader concerns that cannot be accounted for simply by reference to efficiency. ${ }^{19}$ Thus, relying on wealth maximization alone ignores the intricacies of the distribution debate. The payoff for Wittman is the simplicity and logical consistency of his account. However, a "messy" system may be a fair price to pay for one that is more complete. ${ }^{20}$

In The Myth of Democratic Failure, Wittman promises more explanation of how democratic markets operate than he ultimately can deliver. As a freestanding theory of political behavior, Wittman's account is unsatisfying. Approached as a critique of economists' "schizophrenic" view of political markets, though, Wittman's work does succeed in bringing a comprehensive theoretical vision to a chaotic field. The importance of this book will be in shifting future economic research toward "efficiency explanations for the structure of political institutions" (p. 189) and away from a presumption of economic failure in democratic markets.

- Jeffrey Prescott

17. Wittman's theoretical argument also assumes a level of empirical support upon which he cannot reasonably rely. For example, Professors Green and Shapiro argue, with Wittman, that prior empirical work in this field is flawed. See GrEEN \& SHAPIRO, supra note 1, at 7 (arguing that "the bulk of empirical rational choice scholarship is . . . marred by unscientifically chosen samples, poorly conducted tests, and tendentious interpretations of results"). They might see hypocrisy, however, in Wittman's refusal to hold himself to the "necessity for systematic empirical testing in the process of theory elaboration." Id. at 203. This seems a powerful critique of his approach: While admittedly Wittman sees himself as a mere provider of a research strategy, in order to be convincing on any level, his thesis requires a more sophisticated substantive argument.

18. Even Wittman acknowledges that, despite his argument, "there are still many arenas of redistribution" (p. 173).

19. See Hovenkamp, Well-Being, supra note 14, at 98-106 (agreeing that presumption that "political markets work poorly" is counterproductive, but postulating that only "alternative hypotheses" to wealth maximization can explain distributional effects); $c f$. Coase, supra note 8, at 18 (suggesting that real-world existence of high transaction costs can make government action efficient).

20. Grofman, supra note 14 , at 1586 (" $[D]$ emocratic politics . . . is incomplete in that none of its answers are final, and it can be expected to be inefficient, at least as economists use the term. But none of these problems is fatal. They are part of the price we pay for living in a democracy and for being human."). 